\title{
Penanganan distokia karena schistosomus reflexus pada sapi friesian holstein
}

\author{
Nurul Aeni Ayu Lestari ${ }^{1}$, Dhenok Maria Ulva ${ }^{1}$, Nsereko $^{2}$, Mokhamad Fakhrul Ulum ${ }^{3, *}$ \\ ${ }^{1}$ Program Pendidikan Profesi Dokter Hewan, Fakultas Kedokteran Hewan, Institut Pertanian Bogor, Jawa Barat \\ ${ }^{2}$ Staf Medis, Koperasi Serba Usaha Tandangsari, Sumedang, Jawa Barat \\ ${ }^{3}$ Departemen Klinik, Reproduksi, dan Patologi, Fakultas Kedokteran Hewan, Institut Pertanian Bogor, Jawa Barat
}

ABSTRAK: Schistosomus reflexus merupakan kelaianan kongenital berupa dorsoflexi tulang belakang sehingga saat palpasi
perektal akan teraba kepala dan ekstremitas fetus yang berdekatan. Rongga thoraks dan abdomen fetus gagal menutup
sehingga terjadi paparan organ viseral. Tulisan ini melaporkan kasus schistosomus reflexus yang terjadi pada fetus dari seekor
induk sapi Friesian Holstein. Keadaan induk sapi sudah 6 jam mengalami perejanan tanpa disertai adanya kelahiran.
Pemeriksaan palpasi perektal ditemukan kaki belakang fetus melipat ke kepala fetus di jalan kelahiran. Kantung amnion sudah
pecah dan disertai oleh keluarnya intestin fetus. Penanganan dilakukan melalui bedah sesar, namun setelah fetus berhasil
dikeluarkan, beberapa organ fetus menempel pada uterus induk. Jaringan dari organ fetus yang sulit untuk dikeluarkan dari
uterus dibiarkan dan uterus dijahit. Penjahitan kulit, lemak, dan otot dilakukan sekaligus dengan tipe jahitan interlocking
menggunakan benang nilon. Induk sapi kemudian di culling karena persembuhan pascabedah kemungkinan akan sulit bagi
induk sapi untuk kembali bereproduksi akibat sisa jaringan fetus yang masih berada dalam uterus.
Kata kunci:
distokia, Friesian Holstein, schistosomus reflexus, sectio caesaria

\section{- PENDAHULUAN}

Schistosomus reflexus merupakan kelainan kongenital yang umumnya ditemukan pada ruminansia dan menjadi salah satu penyebab distokia pada sapi (Noakes et al. 2002; Pandey et al. 2017). Kelainan yang ditemukan pada kasus schistosomus reflexus adalah dorsoflexi dari tulang belakang sehingga akan teraba kepala dan ekstremitas fetus secara berdekatan saat palpasi perektal dilakukan (Ozcan et al. 2003). Rongga toraks dan abdomen fetus gagal untuk menutup sempurna menyebabkan organ viseral terpapar dalam ruang uterus merupakan diagnosis kasus schistosomus reflexus (Azawi 2012). Organ viseral seperti intestin, jantung, maupun hati umumnya teraba saat dilakukan palpasi (Jackson 2004). Penyebab pasti dari kasus ini belum ditemukan, namun dapat disebabkan oleh faktor genetik, mutasi, infeksi agen, anomali kromosom, faktor lingkungan, maupun gabungan dari beberapa faktor tersebut (Laughton et al. 2005). Beberapa penanganan kasus schistosomus reflexus yang dilakukan adalah fetotomi maupun bedah sesar (Newman dan Anderson 2005).

\section{- KASUS}

Anamnesa dan sinyalmen: Peternak anggota Koperasi Serba Usaha (KSU) Tandangsari, Kabupaten Sumedang melaporkan sapinya menunjukkan gejala partus sejak pukul 03.00 WIB, namun tidak kunjung mengalami partus hingga pukul 09.00 WIB. Sapi berusia 5-6 tahun dengan produksi susu 30 liter/hari. Pemeriksaan klinis: Palpasi pervaginal tidak ditemukan respon gerakan fetus dan tubuh fetus sudah mengeras. Kantung amnion pecah dan cairan keluar dari vagina serta diikuti organ intestinal fetus. Kaki belakang fetus melipat ke kepala di jalan kelahiran. Pemeriksaan fisik: suhu rektal $38.8^{\circ} \mathrm{C}$, frekuensi nafas $68 \mathrm{x} / \mathrm{menit}$, dan frekuensi jantung 136x/menit. Diagnosa: Distokia karena schistosomus reflexus. Prognosa: Dubius-Infausta. Terapi dan penanganan: Penarikan manual dan bedah sesar.

\section{- HASIL DAN PEMBAHASAN}

Penanganan pertama yang dilakukan dengan penarikan manual. Namun fetus tidak dapat dikeluarkan karena kondisi fetus yang sudah mati dengan kondisi tubuh yang abnormal. Kaki belakang fetus terlipat ke kepala fetus dan berada di jalan kelahiran. Sebagaimana yang dilaporkan pada sapi Hariana, serviks sudah membuka sempurna, tulang vertebral, kepala fetus, kaki belakang dan ekor fetus berada di jalan lahir (Patel et al. 2015). Menurut Youngquist dan Threlfall (2007), fetus schistosomus reflexus tidak dapat ditarik paksa dari uterus. Metode penarikan paksa sulit dilakukan sebagaimana pada sapi breed silang, sehingga penanganan yang dilakukan adalah melalui bedah sesar (Sheetal et al. 2018).

Diterima: 25-01-2019 | Direvisi: 14-02-2019 | Disetujui: 17-02-2019

(C) 2019 CC-BY-SA. Ini adalah artikel Open Access yang didistribusikan berdasarkan ketentuan dari Creative Commons Attribution ShareAlike 4.0 International License (https://creativecommons.org/licenses/by-sa/4.0/). 


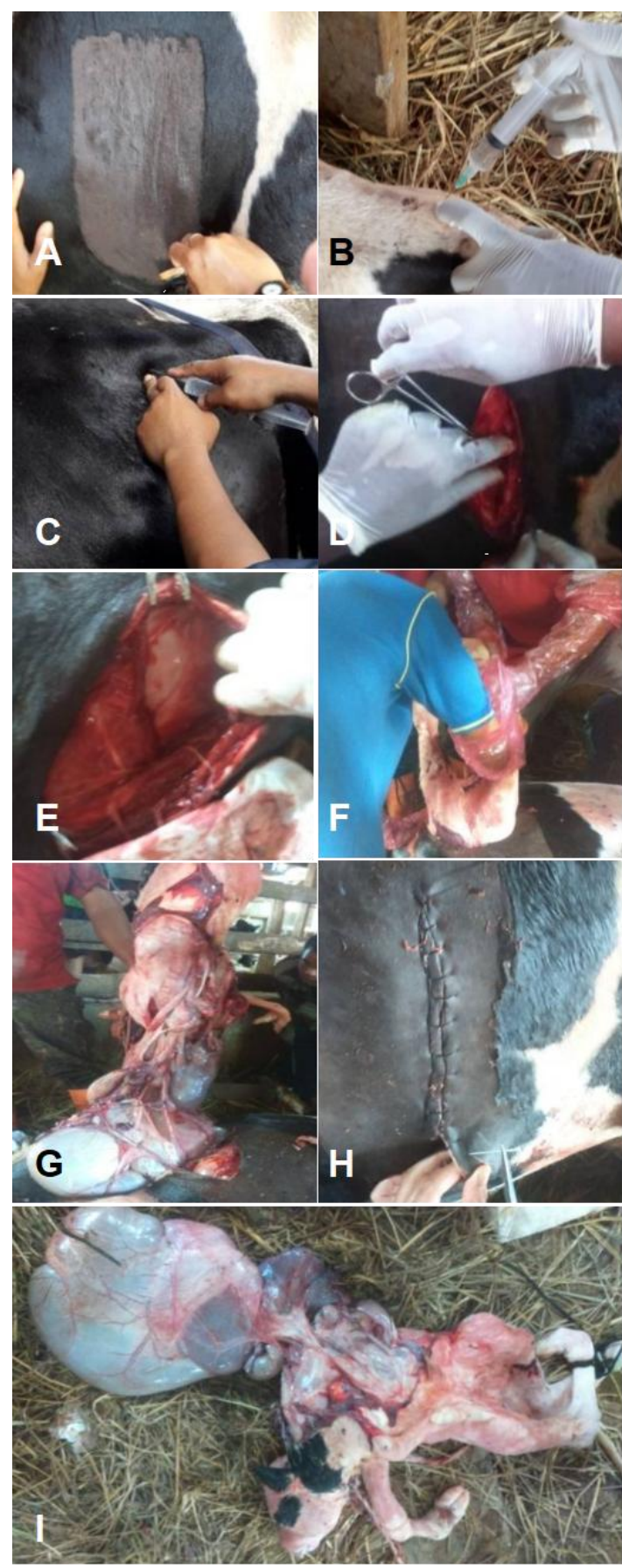

Gambar 1 Bedah sesar penanganan kasus schistosomus reflexus pada sapi Friesian Holstein. (A) Pencukuran dan desinfeksi daerah sayatan, (B) anastesi epidural, (C) anastesi lokal, (D) penyayatan kulit, otot, (E) eksplorasi abdomen dan penyayatan uterus, (F) pengangkatan fetus, $(\mathrm{G})$ organ visceral, $(\mathrm{H})$ penjahitan uterus, otot, dan kulit, dan (I) fetus schistosomus reflexus.

Keadaan induk terbaring lemah akibat kelelahan merejan diberikan infus $100 \mathrm{ml}$ kalsium dan $500 \mathrm{ml}$ ringer laktat (RL). Infus kalsium untuk mengembalikan kadar kalsium darah dan infus RL untuk mencegah syok hipovolemik selama bedah. Bedah sesar dilakukan untuk penanganan kasus ini (Gambar 1). Rambut daerah sayatan dicukur di bagian paralumbal sinistra, disinfeksi menggunakan alkohol $70 \%$ dan povidone iodine. Anastesi epidural menggunakan $5 \mathrm{ml}$ Lidocaine $2 \%$ diantara os coccygea I dan II (Jackson
2004). Antibiotik Penicillin dan Streptomicin $1 \mathrm{ml} / 10 \mathrm{~kg}$ BB intramuskular dan anastesi lokal Lidocaine $2 \%$ subkutan didaerah sayatan. Insisi kulit, $m$. rectus abdominis, dan uterus untuk mencapai fetus. Fetus dikeluarkan dari uterus, namun beberapa organ viscera fetus menempel pada uterus. Tidak terlihat adanya dinding rongga torak dan abdomen pada fetus, sehingga organ viseral terpapar keluar dan langsung bersinggungan dengan uterus. Penarikan dilakukan hingga organ viseral fetus terangkat, namun masih banyak jaringan yang menempel dengan uterus induk. Jaringan yang sulit diangkat dibiarkan. Tidak dilakukan penjahitan uterus. Hal tersebut menyebabkan induk di culling, karena sulitnya penanganan pascabedah akibat sisa jaringan fetus dalam uterus. Penjahitan kulit, otot, dan serosa sekaligus menggunakan benang nilon dengan jahitan interlocking.

\section{- SIMPULAN}

Schistosomus reflexus pada ruminansia menjadi salah satu penyebab distokia. Penanganan bedah sesar pada kasus distokia akibat schistosomus reflexus dilakukan karena usaha penarikan manual tidak berhasil mengeluarkan fetus.

\section{n INFORMASI PENULIS}

Penulis untuk Korespondensi

*MFU: ulum@ipb.ac.id

Departemen Klinik, Reproduksi, dan Patologi

Fakultas Kedokteran Hewan, Institut Pertanian Bogor

J1 Agatis, Kampus IPB Dramaga, Bogor 16680

\section{- PUSTAKA ACUAN}

Azawi OI, Ahmed OS, Abass SF. 2012. Schistosomus reflexus foetus in cross breed Iraqi cow: a case report. Iraqi Journal of Veterinary Sciences. 26(2): 103-104.

Jackson PGG. 2004. Handbook of Veterinary Obstetrics 2nd Edition. USA: Elsevier Sci Ltd. Hlm 16.

Laughton KW, Fisher KRS, Halina WG, Partlow GD. 2005. Schistosomus reflexus syndrome: A heritable defect in ruminants. Anat Histol Embryol. 34:312-318.

Newman KD, Anderson DE. 2005. Cesarean section in cows. Vet Clin Food Anim Practice. 21: 73-100.

Noakes DE, Parkinson TJ, England GCW, Arthur GH. 2002. Arthur's Veterinary Reproduction and Obstetrics 8th Edition. USA: Elsevier Sci Ltd. Hlm 129-212.

Ozcan K, Ozturkler Y, Tuzcu M, Erginosoy S. 2003. Schistosomus reflexus in cattle in Kars province. Indian Vet J. 80: 693-694.

Pandey AK, Kumar S, Gunwant P, Verma A, Phogat JB. 2017. Schistosomus reflexus monster fetus in bovine and its successful management. Research Journal for Veterinary Practitioners. 5(2): $25-27$

Patel A, Yadav SS, Yadav D, Sonker V, Saxena A. 2015. Dystocia due to scistosomus reflexus in a Hariana Cow. International Journal of Livestock Research. 5(4): 122-124

Sheetal SK, Patil AD, Sahatpure SK, Gahlod BM, Akhre SB. 2018. Management of dystocia due to schistosoma reflexus in a crossbred cow. Journal of Veterinary Science and Reaserch. 3(3): 1-2

Youngquist RS, Threlfall WR. 2007. Current Therapy in Large Animal Theriogenology 2nd Edition. Philadelphia (USA): Saunders. Hlm 313-468. 